\title{
Sistem Informasi Akademik Monitoring Perkuliahan Di Politeknik Gorontalo
}

\author{
Ismail Mohidin ${ }^{\left.{ }^{*}\right)}$ \\ Program Studi Teknik Informatika, Politeknik Gorontalo \\ 60111, ${ }^{1^{*}}$ email : ismail.mohidin@poligon.ac.id,
}

\begin{abstract}
Monitoring perkuliahan merupakan kegiatan proses belajar mengajar yang dilakukan oleh dosen. Sehingga dalam proses monitoring perkuliahan dapat lebih terkontrol dan lebih up to date karena melibatkan kesatuan luar yang terhubung dalam suatu sistem. Kegiatan monitoring perkuliahan merupakan kegiatan akademik yang dilakukan oleh Program Studi di masingmasing jurusan yang bertujuan untuk memantau penerapan standar proses pembelajaran yang dilakukan oleh dosen secara terus menerus dan untuk pengambilan tindakan berdasarkan kondisi yang ada.

Penelitian ini bertujuan untuk membangun sistem informasi akdemik yang terintegrasi keseluruh satuan kerja yang ada di Politeknik Gorontalo, tujuannya untuk memudahkan mahasiswa, dosen dan bagian akademik dalam mencari informasi, tentang perkembangan proses belajar mengajar dalam setiap kelas. Di Politeknik sendiri belum ada sistem terintegrasi untuk melihat dan memantau perkembangan dari setiap proses pembelajaran sehingga banyak menimbulkan permasalahan dilapangan, maka perlu merancang sebuah sistem yang akan membantu dan monitoring setiap perkembangan proses belajar mengajar setiap perkulihan selain itu juga dalam system ini terdapat beberapa fitur yang akan ditambakan seperti nilai akhir mahasiswa, Kartu Hasil Studi dan Transkrip Nilai.
\end{abstract}

\section{Kata Kunci : Monitoring Perkuliahan}

\section{PENDAHULUAN}

Perkembangan teknologi yang semakin maju di era globalisasi seperti sekarang ini menuntut sumber daya manusia yang berkualitas dalam hal komputerisasi bagi semua kalangan, baik dari segi pendidikan maupun dalam dunia bisnis. Dengan adanya internet saat ini bisa membuat penyebaran informasi menjadi cepat dan maju serta mudah diakses oleh mahasiswa dan dosen. Kemudahan dalam memperoleh informasi ini dapat meningkatkan kemampuan berkembangnya suatu organisasi pada institusi Perguruan Tinggi seperti Akademi, Sekolah Tinggi, Institut maupun Politeknik. Keberadaan sebuah sistem informasi sudah merupakan sebuah kebutuhan utama.

Kemudahan inilah yang dijadikan alasan oleh institusi untuk menggunakan sistem informasi sebagai media komunikasi informasi bagi mahasiswa. Politeknik Gorontalo sebagai salah satu perguruan tinggi favorit di Gorontalo tentunya tidak mau tertinggal secara teknologi. Perkembangan

\author{
Eton R. Husin ${ }^{2)}$ \\ Program Studi Teknik Informatika, Politeknik Gorontalo \\ 60111, email : etonhusin23@gmail.com
}

terus diupayakan secara bertahap. Salah satu yang diupayakan adalah membuat Sistem Informasi Akademik (SIAKAD) untuk memudahkan mahasiswa dan dosen dalam mencari informasi.

Studi kasus ini dilakukan di Politeknik Gorontalo, karena kampus tersebut belum memiliki SIAKAD. sistem yang akan diusulkan terdapat beberapa modul, akan tetapi, pada tulisan ini hanya membahas salah satu modul yaitu monitoring perkuliahan menjadi permasalahan yang sering ditemui yaitu proses pengolahan data monitoring perkuliahan, membuat hasil nilai akhir mahasiswa, Kartu Hasil Studi dan Transkrip Nilai selalu terjadi kesalahan dan keterlambatan dalam pengolahan data setiap mahasiswa. Dikarenakan dengan bertambah banyaknya jumlah mahasiswa yang masuk di Politeknik Gorontalo, maka semakin banyak data hasil Kartu Hasil Studi dan Transkrip Nilai yang harus di sediakan oleh Program Studi, Sehingga mahasiswa sulit untuk melihat transkrip nilai dan rangking setiap semester dengan menunggu konfirmasi dari pihak program studi. Dengan kondisi seperti ini, maka penulis akan membuat sistem yang terintegrasi di mana setiap mahasiswa dan dosen dapat melihat hasil kartu hasil studi mahasiswa per semester. Sistem akademik ini memungkinkan mahasiswa untuk melihat dan mengolah data perkuliahan, antara lain berupa informasi transkrip nilai dan KHS (Kartu Hasil Studi). Di samping itu mahasiswa juga bisa mencetak hasil transkrip nilai. Semua data-data tersebut dapat dilihat oleh mahasiswa melalui situs sistem informasi akademik Politeknik Gorontalo. Diharapkan dengan adanya sistem yang akan dibangun ini bisa mengatasi dan mempermudah bagian akademik dan program studi yang ada di Politeknik Gorontalo.

\section{METODE PENELITIAN}

Gambaran Umum Sistem

Gambaran umum proses berjalannya monitoring perkuliahan di Politeknik Gorontalo yang akan di ilustrasikan seperti gambar dibawah ini:

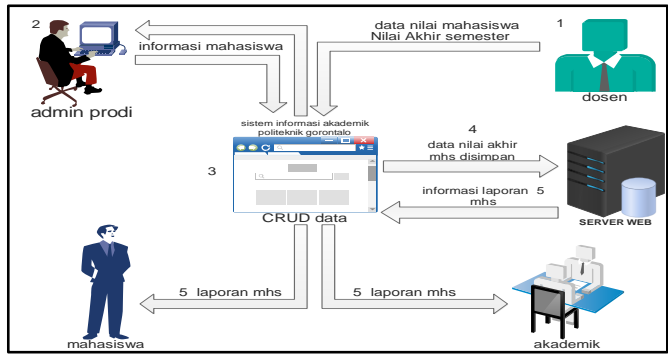

Gambar 1. Gambaran umum sistem 
Deskripsi dari Gambar 1 adalah sebagai berikut ini :

1. Data nilai mahasiswa dari setiap dosen diinputkan kedalam sistem.

2. Admin prodi dapat menampilkan data nilai setiap mahasiswa dari dosen yang bersangkutan.

3. Data nilai dari setiap mahasiswa di inputkan kedalam server akademik Politeknik Gorontalo.

4. Data disimpan pada sistem basis data.

5. Data yang disimpan di jadikan sebuah laporan untuk bagian mahasiswa dan akademik yang membutuhkannya.

Setiap dosen yang mempunyai hak akses kedalam sistem dapat melakukan menampilkan data nilai mahasiswa, membuat, mengedit, dan menghapus data. Nilai-nilai yang diinputkan yaitu berupa nilai akhir mahasiswa selama semester yang dijalani. Sehingga mempermudah bagian akademik program studi untuk melakukan rekapan nilai setiap mahasiswa.

Pada bagian akademik program studi dapat melakukan menampilkan sebuah data nilai dari setiap mahasiswa yang diinputkan dari setiap dosen. Selain itu bagian akademik program studi juga dapat membuat, mengedit dan menghapus data yang terdiri dari data rekapan nilai, transkrip nilai, Kartu Hasil Studi. Serta dapat membuat laporan dari setiap data-data yang dibutuhkan.

Mahasiswa yang membutuhkan data - data nilai berupa Kartu Hasil Studi dan Transkrip Nilai dapat melakukan dengan cara mengakses sistem informasi akademik Politeknik Gorontalo dan mencetak laporan yang telah disediakan.

Bagian akademik juga dapat mencetak laporan dari setiap data nilai mahasiswa untuk dijadikan laporan untuk disimpan.

\section{Diagram Dasar Dalam UML}

Berdasarkan observasi yang telah dilakukan pada bagian akademik program studi Teknik Informatika masih harus datang ke kampus untuk mendapatkan sebuah data mahasiswa yang akan di ilustrasikan seperti gambar 2:

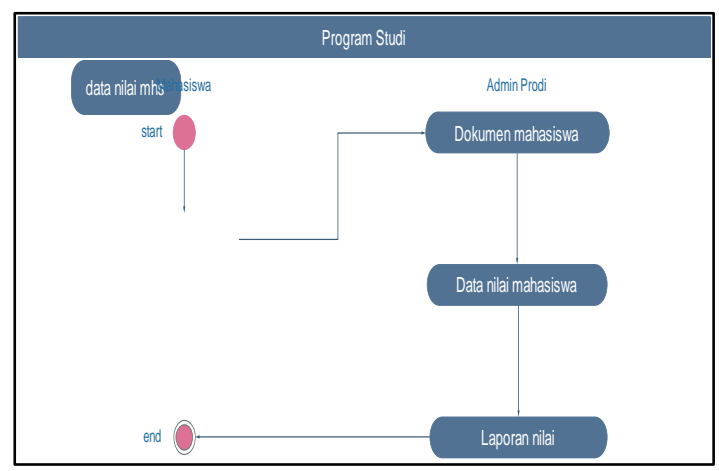

Gambar 2. Activity diagram yang berjalan

Berdasarkan penjelasan gambar 2 tentang Activity Diagram diatas yang berjalan, pertama yang harus dilakukan oleh mahasiswa yaitu dengan cara datang ke kampus untuk mendatangi bagian akademik program studi untuk melihat hasil laporan data-data mahasiswa. Sehingga pada bagian akademik program studi akan melakukan pencarian data-data mahasiswa dan mencetak hasil berupa laporan untuk diberikan pada mahasiswa yang membutuhkan.

\section{Use Case Diagram yang diusulkan}

pada gambar 3 use case berikut ini merupakan uraian antar muka atau gambaran umum kegiatan yang akan dilakukan oleh pengguna sistem informasi akademik yang terdiri dari dosen, admin prodi, mahasiswa dan bagian akademik sesuai dengan modul yang sudah di bagi beberapa modul untuk pembuatan aplikasi monitoring perkuliahan di Politeknik Gorontalo.

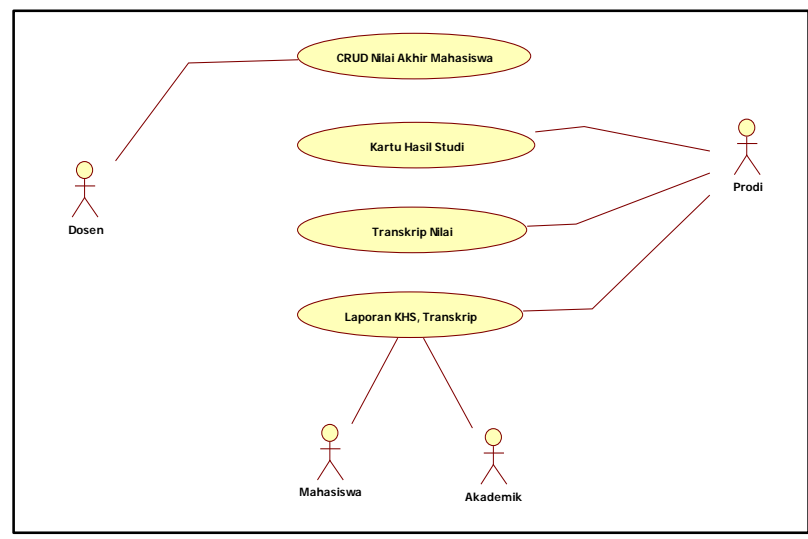

Gambar 3. Use case diagram yang diusulkan

Tabel Deskripsi Use Case Sistem Usulan

\begin{tabular}{|c|c|}
\hline Nama Use Case & Tujuan Use Case \\
\hline CRUD Nilai Akhir & Use Case ini bisa memberikan \\
\hline Mahasiswa & $\begin{array}{l}\text { kemampuan untuk menampilkan } \\
\text { membuat Input nilai, dan edit nilai } \\
\text { mahasiswa }\end{array}$ \\
\hline Kartu Hasil Studi & $\begin{array}{l}\text { Use Case ini bisa memberikan } \\
\text { kemampuan untuk membuat laporan } \\
\text { khs selama semester yang di jalanani } \\
\text { yang akan di proses oleh mahasiswa. }\end{array}$ \\
\hline Transkrip Nilai & $\begin{array}{l}\text { Use Case ini bisa memberikan } \\
\text { kemampuan untuk membuat laporan } \\
\text { transkrip nilai. }\end{array}$ \\
\hline $\begin{array}{l}\text { Laporan KHS, } \\
\text { Transkrip }\end{array}$ & $\begin{array}{l}\text { Use Case ini bisa memberikan hasil } \\
\text { laporan dari KHS dan Transkrip Nilai }\end{array}$ \\
\hline
\end{tabular}

Sequence diagram aktor prodi 


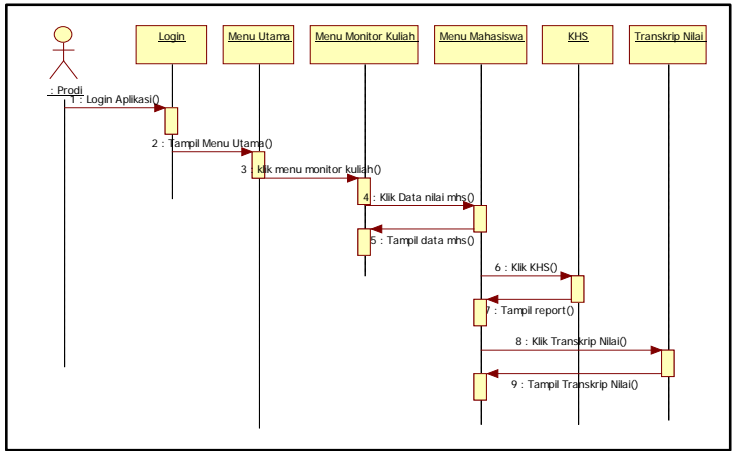

Gambar 4 sequence diagram actor prodi

Tabel 5 Deskripsi Sequence diagram prodi

\begin{tabular}{cl}
\hline Nama Use Case & \multicolumn{1}{c}{ Tujuan Use Case } \\
\hline Prodi & Admin prodi disini adalah sebagai \\
& pengguna pada sistem SIA \\
& Monitoring Perkuliahan Politeknik \\
& Gorontalo. \\
Login & Prodi melakukan login untuk \\
& mendapatkan akses pada sistem. \\
Menu Utama & Menampilakan Form Menu Utama \\
& Program Studi. \\
Menu Monitor & Menampilkan Form untuk semua \\
Kuliah & data nilai mahasiswa. \\
Mahasiswa & Pada form ini untuk menampilkan \\
& semua data mahasiswa sesuai \\
& semester. \\
KHS & Membuat report untuk Kartu Hasil \\
& Studi. \\
Transkrip Nilai & Membuat report untuk Transkrip \\
& Nilai.
\end{tabular}

Sequence diagram actor dosen

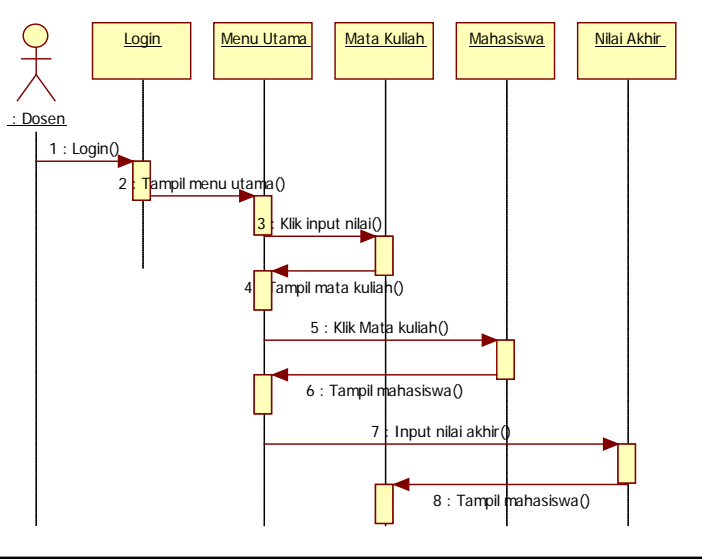

Gambar 5 sequence diagram actor dosen
Tabel 6 Deskripsi Sequence diagram dosen

\begin{tabular}{|c|c|}
\hline Nama Use Case & Tujuan Use Case \\
\hline \multirow[t]{4}{*}{ Dosen } & $\begin{array}{llll}\text { Dosen } & \text { disini } & \text { adalah } & \text { sebagai }\end{array}$ \\
\hline & pengguna pada sistem SIA \\
\hline & Monitoring Perkuliahan Politeknik \\
\hline & Gorontalo. \\
\hline Login & $\begin{array}{l}\text { Dosen melakukan login untuk } \\
\text { mendapatkan akses pada sistem. }\end{array}$ \\
\hline Menu Utama & $\begin{array}{l}\text { Menampilakan Form Menu Utama } \\
\text { sesuai program studi yang diajar. }\end{array}$ \\
\hline Mata Kuliah & $\begin{array}{l}\text { Menampilkan Mata kuliah yang di } \\
\text { ampuh sesuai semester. }\end{array}$ \\
\hline Mahasiswa & $\begin{array}{l}\text { Menampilkan nama mahasiswa } \\
\text { sesuai mata kuliah yang diajar. }\end{array}$ \\
\hline Input Nilai Akhir & $\begin{array}{l}\text { Form ini untuk menginput nilai } \\
\text { akhir. }\end{array}$ \\
\hline
\end{tabular}

\section{Sequence diagram actor mahasiswa}

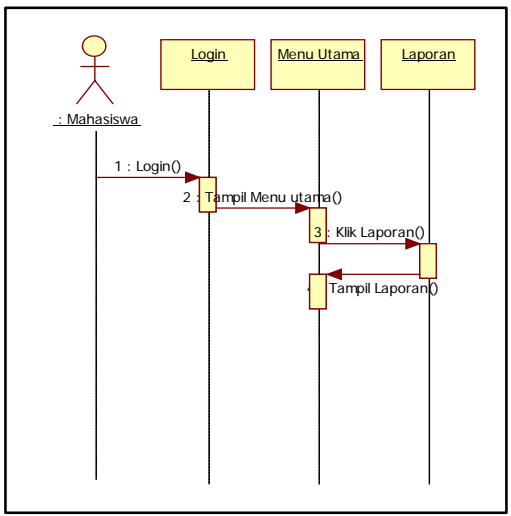

Gambar 6 sequence diagram actor mahasiswa

Tabel 7 Deskripsi Sequence diagram mahasiswa

\begin{tabular}{cl}
\hline Nama Use Case & \multicolumn{2}{c}{ Tujuan Use Case } \\
\hline Mahasiswa & Mahasiswa disini adalah sebagai \\
& pengguna pada sistem SIA \\
& Monitoring Perkuliahan Politeknik \\
& Gorontalo. \\
Login & Mahasiswa melakukan login untuk \\
& mendapatkan akses pada sistem. \\
Menu Utama & Menampilakan Form Menu Utama \\
& sesuai program studi. \\
Laporan & Menampilkan report sesuai yang \\
& dicetak sebagai \\
Mahasiswa & Mahasiswa disini adalah seba \\
& pengguna pada sistem SIA \\
& Monitoring Perkuliahan Politeknik \\
& Gorontalo.
\end{tabular}




\section{Sequence diagram actor akademik}

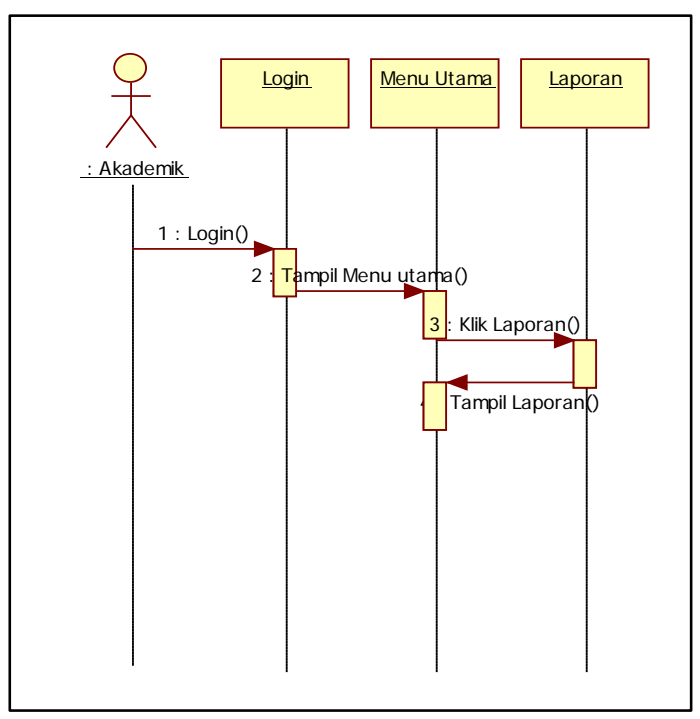

Gambar 7 sequence diagram actor akademik

Tabel 8 Deskripsi Sequence diagram akademik

\begin{tabular}{cl}
\hline Nama Use Case & \multicolumn{2}{c}{ Tujuan Use Case } \\
\hline Akademik & Akademik disini adalah sebagai \\
& pengguna pada sistem SIA \\
& Monitoring Perkuliahan Politeknik \\
& Gorontalo. \\
& Akademik melakukan login untuk \\
Login & mendapatkan akses pada sistem. \\
Menu Utama & Menampilakan Form Menu Utama \\
& sesuai program studi. \\
Laporan & Menampilkan report sesuai yang \\
& dicetak \\
\hline
\end{tabular}

\section{IMPLEMENTASI}

Setelah sistem dianalisis dan didesain secara rinci, maka akan menuju tahap implementasi. Implementasi merupakan tahap meletakan sistem siap untuk dioperasikan. Implementasi bertujuan untuk mengkonfirmasi modul-modul perancangan, sehingga pengguna dapat memberikan masukan kepada pembangunan sistem.

Halaman Login Aplikasi menampilkan halaman login sistem, yaitu halaman dimana semua user melakukan proses login untuk dapat menggunakan Sistem Informasi Akademik Politeknik Gorontalo.

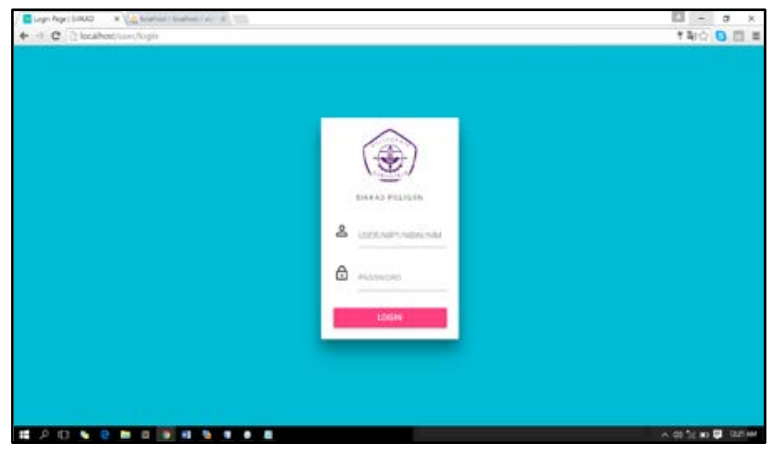

Gambar 8. Hasil Form login

Halaman Form Dosen menjelaskan dimana dosen yang sudah melakukan proses login akan diarahkan ke halaman dosen yang telah disediakan. Pada menu monitor kuliah maka akan di arahkan untuk menginput nilai mahasiswa.

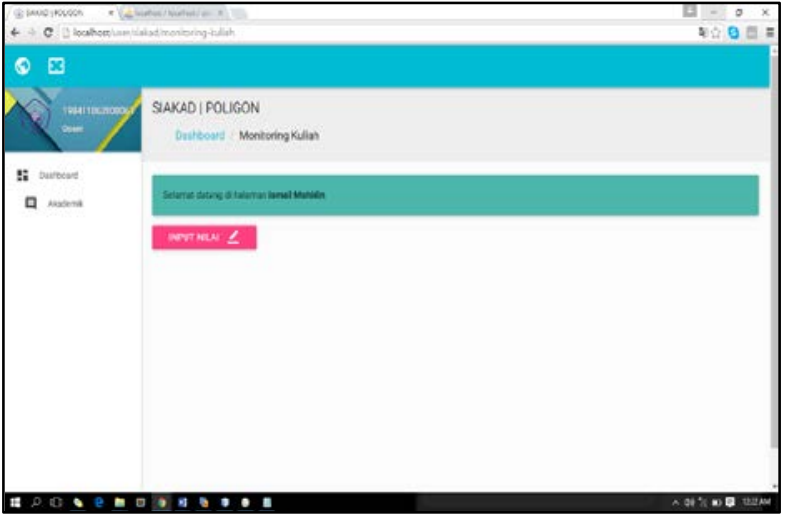

Gambar 9. Hasil Menu dosen input nilai

Halaman Mata Kuliah Yang Diampuh akan menampilkan mata kuliah yang diampuh berdasarkan semester yang diajarkan sehingga dosen tinggal memilih untuk menginput nilai pada mata kuliah yg dipilih.

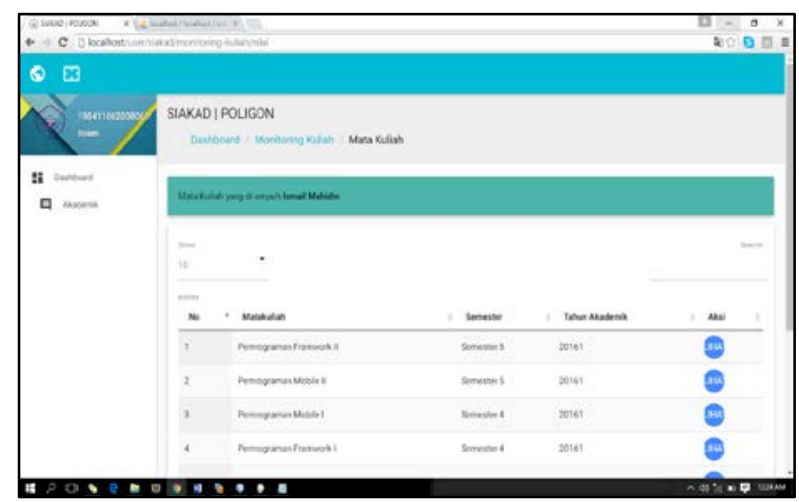

Gambar 10. Hasil Mata Kuliah yang diampuh

Halaman ini, menampilkan nama - nama mahasiswa yang akan di inputkan nilainya berdasarkan mata kuliah yang dipilih dan semester. Sehingga dosen dengan mudah 
menginputkan nilai dengan memilih mahasiswa yang akan di inputkan nilainya.

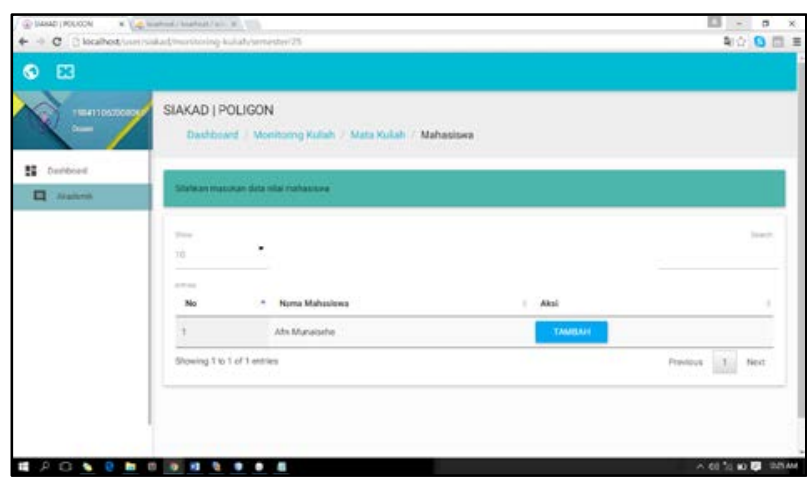

Gambar 11. Hasil Nama Mahasisa

Halaman ini, menginputkan nilai akhir mahasiswa setelah mengikuti ujian akhir semester. Sehingga setelah diinputkan maka nilai akhir tersebut akan di kirimkan langsung ke bagian program studi. Dan memudahkan admin prodi dalam pembuatan report KHS maupun Transkrip nilai.

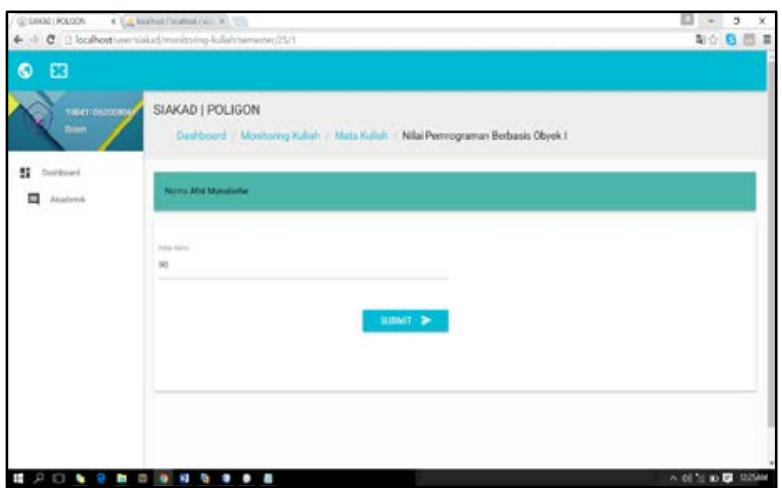

Gambar 12. Hasil Input nilai mahasiswa

Halaman ini, menampilkan bagian prodi yang sudah melakukan proses login akan di arahkan ke halaman program studi yang telah dibuat.

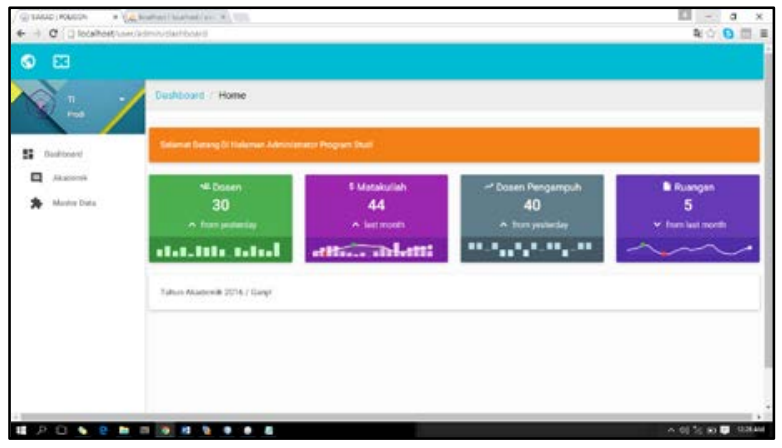

Gambar 13. Hasil Halaman program studi
Pada halaman ini, program studi yang dapat melihat data - data nilai akhir mahasiswa yang telah di inputkan oleh dosen dan akan secara otomatis masuk pada bagian program studi.

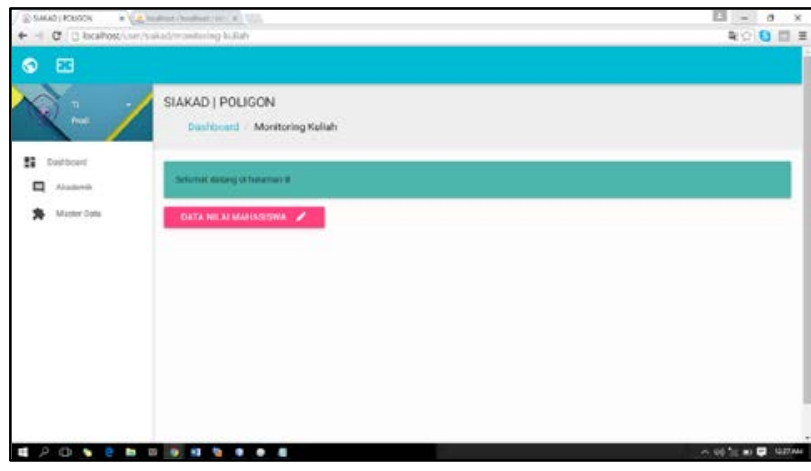

Gambar 14. Hasil data nilai mahasiswa

menampilkan data data mahasiswa yang sudah masuk nilai akhirnya dari semester terbawah sampai semester terakhir beserta tahun akademik yang sudah berjalan maupun yang sudah berakhir. Sehingga data data yang akan diperlukan dapat dicari pada halaman ini.

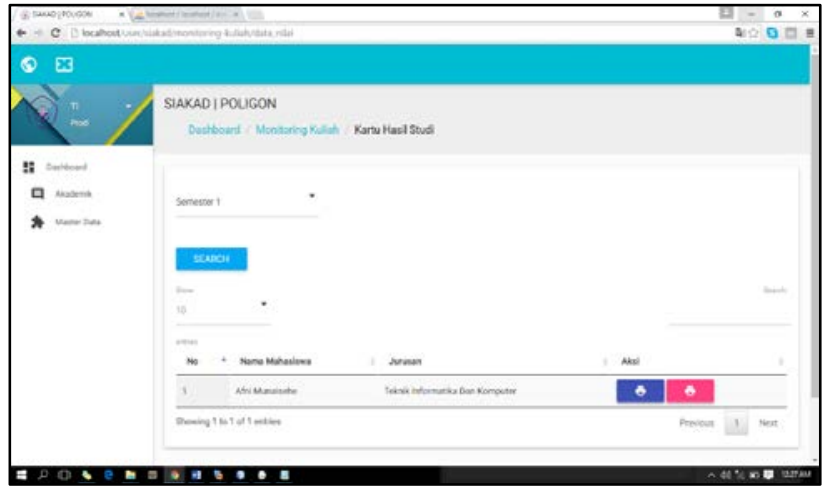

Gambar 15. Hasil Menampilkan data data mahasiswa

Halaman ini, menampilkan mahasiswa yang sudah melakukan proses login akan diarahkan ke halaman mahasiswa yang telah dibuat dan dapat melakukan pencetakan KHS dan Transkrip Nilai. 


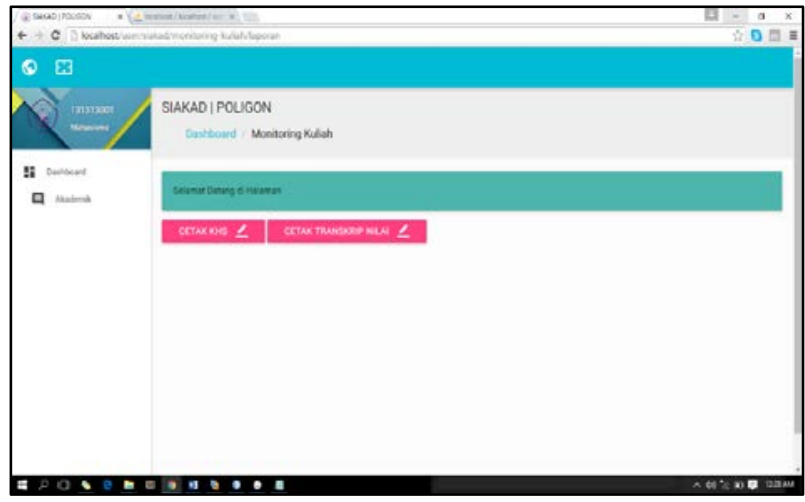

Gambar 16. Hasil halaman cetak mahasiswa

Halaman ini, menampilkan mahasiswa dapat mencetak KHS yang sudah ada dengan cara memilih semester yang sudah ditempuh sebelumnya.

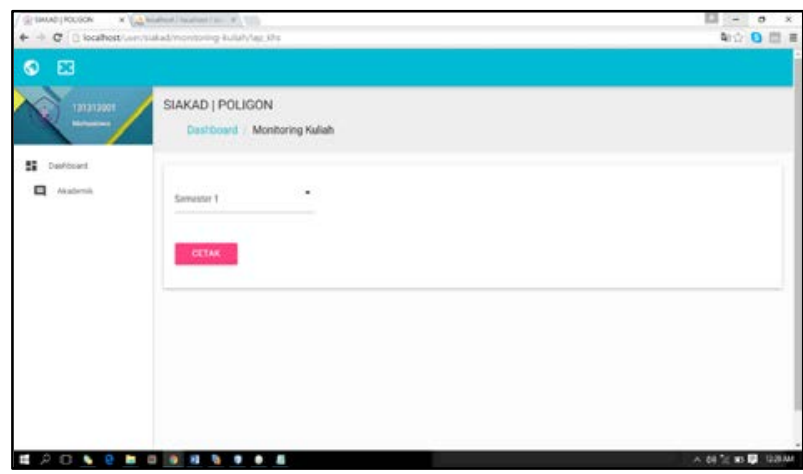

Gambar 17. Hasil cetak kartu hasil studi mahasiswa

Halaman ini, menampilkan bagian akademik yang sudah melakukan proses login akan di arahkan ke halaman akademik yang telah dibuat. Pada halaman ini terdiri dari beberapa menu yang dapat di akses. Akademik dapat melakukan pencetakan KHS mahasiswa dari tiga program studi yang ada di Politeknik Gorontalo. Baik itu dari semester pertama maupun semester akhir.

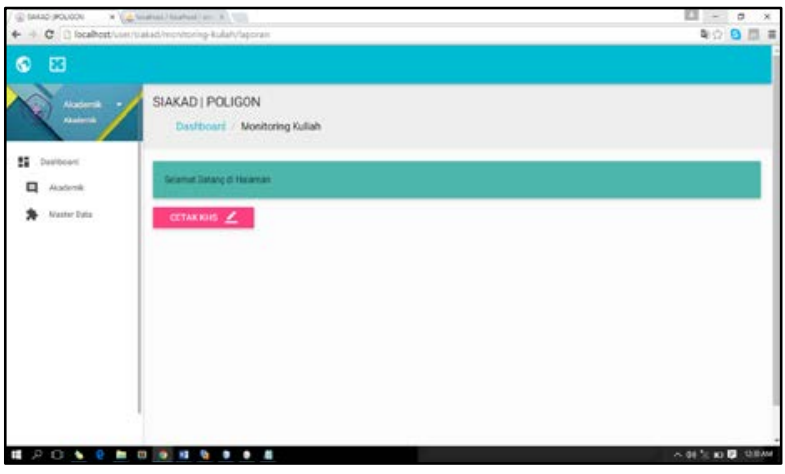

Gambar 18. Hasil cetak khs bagian akademik

tampilan halaman hasil data nilai mahasiswa yang akan menampilkan bagian akademik untuk melakukan pencetakan kartu hasil studi mahasiswa sesuai semester dan program studi yang telah dipilih, maka akan ditampilkan hasilnya.

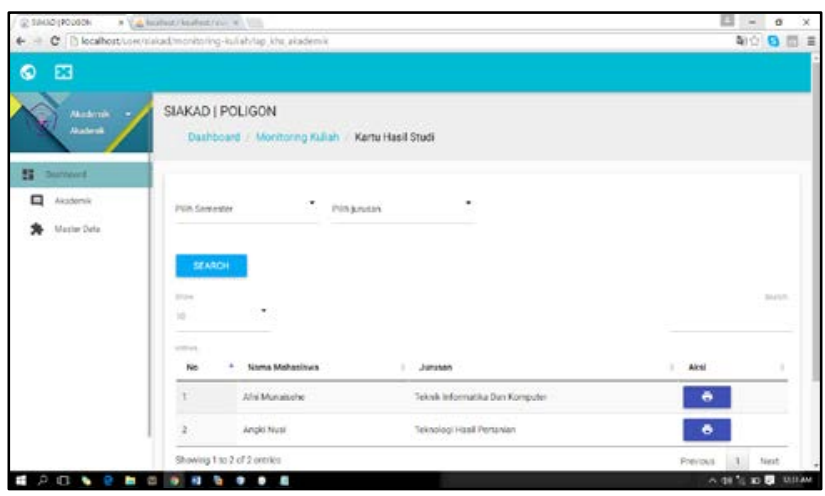

Gambar 19. Hasil data mahasiswa pada bagian akademik

tampilan halaman cetak pada bagian prodi, mahasiswa, maupun bagian akademik dapat melakukan pencetakan kartu hasil studi.

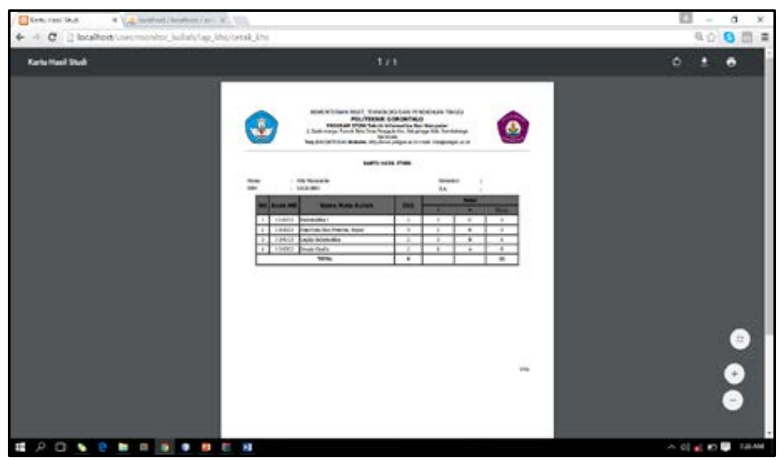

Gambar 20. Hasil KHS

tampilan halaman cetak pada bagian prodi, mahasiswa, maupun bagian akademik dapat melakukan pencetakan transkrip nilai.

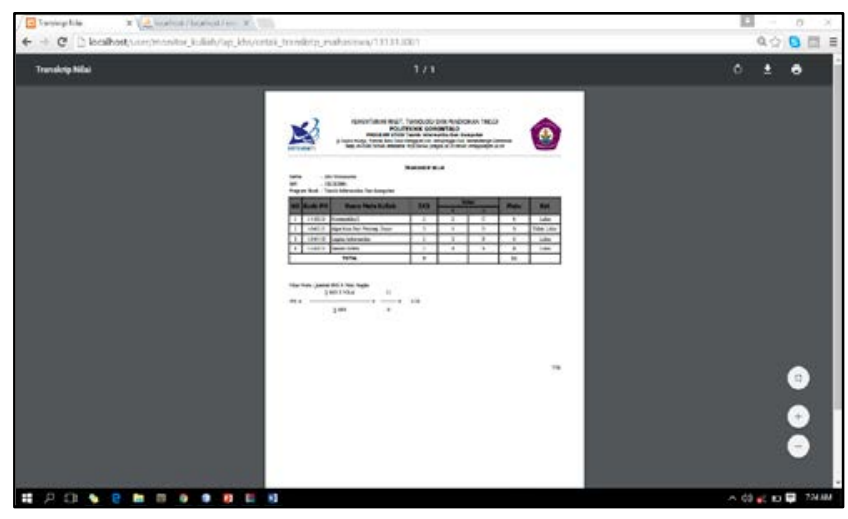

Gambar 21. Hasil Transkrip Nilai 


\section{Kesimpulan}

\section{PENUTUP}

Setelah dilakukan uji coba dan evaluasi terhadap sistem informasi monitoring perkuliahan, maka dapat ditarik kesimpulan sebagai berikut :

1. Sistem ini dapat menganalisa hasil evaluasi kelas berupa informasi sebagai berikut : produktivitas kelas, perbandingan keberhasilan materi antar kelas, tingkat penguasaan materi dalam satu kelas, dan korelasi antar materi berdasarkan hasil evaluasi kelas.

2. Sistem ini dapat menghasilkan perbandingan hasil evaluasi per materi antar kelas dengan. Sistem ini dapat memberikan informasi apakah terdapat perbedaan signifikan pada hasil evaluasi permateri antar kelas.

\section{Saran}

Adapun beberapa saran yang dapat diberikan kepada peneliti berikutnya apabila ingin mengembangkan sistem yang telah dibuat ini agar menjadi lebih baik adalah sebagai berikut:

1. Tampilan web untuk sistem yang dibuat ini masih sederhana sehingga perlu ditingkatkan lagi kualitasnya.

2. Aplikasi mendatang sebaiknya menggunakan enkripsi data atau teknologi lainnya untuk keamanan data di internet

3. Aplikasi mendatang sebaiknya bisa menangani soal ujian dengan tipe multiple choice. Bisa juga ditambahkan fitur ujian secara online sehingga mahasiswa mengerjakan ujian secara langsung pada aplikasi ini. Hasil ujian mahasiswa bisa langsung diproses oleh sistem sehingga dosen/pengajar tidak perlu lagi melakukan input nilai secara manual.

\section{DAFTAR PUSTAKA}

Jogiyanto, Muttaqin, F., \& Musadieq, M. Al. 2014. Analisis Dan Desain Sistem Informasi Berbasis Komputer Untuk Persediaan Barang Pada Toko Bahan Bangunan (Studi Kasus pada UD. Sumber Bumi Subur); 8(1); 1-7.

Koespradono, Suraya, Y. R. K. 2013. Sistem Informasi Pengolahan Data Pertumbuhan Ekonomi Dan Ketimpangan Di Kabupaten Klaten (Tahun 2003-2012) Menggunakan Framework Codeigniter; 1(1); 46-54.

Liatmaja, I. U. W. 2013. Sistem Informasi Akademik Berbasis Web Pada Lembaga Bimbingan Belajar Be Excellent Pacitan; 58-63.

Priyanto W. 2003. Sistem Informasi Monitoring Perkuliahan Berbasis Web Di STMIK Sinar Nusantara Surakarta; 53.

Saputra, R. 2015. Desain sistem informasi order photo pada creative studio photo dengan menggunakan bahasa pemrograman visual basic. 17(2); 86-93.

Sophian, S. 2014. Penginplementasian Dan Perancangan Sistem Informasi Penjualan dan Pengendalian Stok Barang Pada Toko Swastika Servis (SS) Bangunan Dengan Menggunakan Bahasa Pemograman Visual Basic 6.0 Didukung dengan Database MySQL) 16(1); 1-5. http://doi.org/10.1007/s13398-014-0173-7.2

Sulistyorini, P. (2009). Pemodelan Visual dengan Menggunakan UML dan Rational Rose; XIV(1); 23-29.

Yendri, D., \& Sovia, R. 2012. Perancangan Sistem Informasi Akademik Nilai Siswa Berbasis Web (Studi Kasus: SMK Ciledug Al-Musaddadiyah Garut); 5(1); 97-106. 